\title{
Studies on the Development and Storage of Whey based RTS Beverage from Mango CV. Kesar
}

\section{Sakhale BK ${ }^{1}$, Pawar VN² and Ranveer $\mathrm{RC}^{3 *}$}

${ }_{1}^{1}$ Food Technology Division, Department of Chemical Technology, Dr. Babasaheb Ambedkar Marathwada University, Aurangabad (MS), India

${ }^{2}$ Department of Food Science and Technology, M. A. U., Parbhani (MS), India

${ }^{3}$ Department of Food Science and Technology, Shivaji University, Kolhapur (MS), India

\begin{abstract}
Whey and juice of mango (Cv. Kesar) were utilized at various combinations (70:30, 75:25 and 80:20) for preparation of nutritious ready-to-serve (RTS) beverages and evaluated for various physico-chemicals and sensory attributes during storage. The study revealed that the RTS beverage prepared with $70 \%$ whey and $30 \%$ mango juice scored maximum for almost all sensorial quality attributes such as appearance, color, flavor, taste and overall acceptability and also found highest in ascorbic acid content $(9.80 \mathrm{mg} / 100 \mathrm{~g})$. A reducing trend was observed in total sugars and ascorbic acid and increasing trend was observed in reducing sugars and acidity content during the storage of beverage at refrigeration temperature over a period of 30 days. The beverage remained unchanged with respect to TSS content along the storage period.
\end{abstract}

Keywords: Whey; Mango; RTS beverage; Sensory characteristics; Storage

\section{Introduction}

Soft beverage industry has made significant progress during last several years in terms of production, but there is only a limited range of flavors available in India. Many types of syrups, sherbets and soft drinks containing artificial fruit flavors are well known throughout the world. The basic factor considered is the nutritive and therapeutic values, which make them popular and acceptable. At present fruit beverages are generally synthetic flavored, bottled and sold in the market. If this could be substituted with fruit juice and dairy whey, it will be more beneficial to the consumer, dairy industries and beverage manufacturers and fruit growers.

Beverages based on whey continue to receive a considerable amount of attention reflecting a growing awareness of the potential of these products in the market place. These beverages have high nutritional quality and increased energy value. These could be particularly useful in place where there is lack of food and improper nutrition leading to deficiencies of certain nutrients. Whey is the watery liquid remaining after milk has been curdled and strained. It contains about half of the total solids of milk and source of precious nutrients like whey proteins, lactose, milk salts and most of water-soluble vitamins [1]. Whey possesses preventive and curative elements and is especially used to treat a wide variety of ailments such as arthritis, anemia and liver complaints [2]. In India, whey is obtained as a by-product in the preparation of channa, paneer, cheese and casein. About 3 million tonnes of whey is produced annually in India containing about 2 lakh tonnes of valuable milk nutrients [1].

Therefore, conversion of whey into fermented or non-fermented beverages is one of the most attractive avenues for utilization of whey for human consumption. The development of any process for its economical utilization would be of great benefit to the dairy industry. At this stage, product diversification using whey as a partial replacement of water without much change in the existing infrastructure is quite feasible.

The development of nutritionally value added product could therapeutically help on improving the health of consumers. Mango pulp and dairy whey can be utilized to make the product therapeutic, prophylactic and nutritionally rich which may increase its demand in food and beverage industry. Introduction of new types of value added beverages might improve socio-economic status of the country.

Mango (Mangifera indica L.) is one of the favored fruits in the tropical and sub-tropical regions. It has an excellent flavor, attractive fragrance, delicious taste and high nutritional value that have made it one of the best fruits [3].

Many attempts have been reported on utilization of whey in the formulation of various dairy products but still there is a lot of scope to explore the possibility of its utilization in beverage industries. The researchers reported preparation of fruit flavored beverages using whey obtained from coagulation of cow milk [4]. Singh et al. [5] formulated a whey based mango beverages with $15 \%$ pulp and $78 \%$ whey. Soft beverage from paneer whey and guava was developed [6], while Sikder et al. [7] formulated different blends of whey beverages by using various levels of mango pulp (8-12\%) of four different varieties.

Indian dairy industry is looking for new product ideas and technologies to meet consumers' requirements and to increase profitability of the products. Product diversification is quite feasible using whey as a water replacer without much change in the infrastructure. India has plenty of fruits that are a good source of vitamins and minerals. As production of fruits is seasonal, there is a glut in the market during a particular season. Mango fruits are an excellent source of vitamin A and $\mathrm{C}$, as well as a good source of potassium and contain beta-carotene. Mangos are high in fiber, but low in calories (approx. 110 per average sized mango), traces amount of fat and sodium. During market glut in the season, the pulp/juice from

*Corresponding author: Ranveer RC, Department of Food Science and Technology, Shivaji University, Kolhapur (MS), India, E-mail: rahul.ranveer@gmail.com

Received February 13, 2012; Accepted March 12, 2012; Published March 15, 2012

Citation: Sakhale BK, Pawar VN, Ranveer RC (2012) Studies on the Development and Storage of Whey based RTS Beverage from Mango cV. Kesar. J Food Process Technol 3:148. doi:10.4172/2157-7110.1000148

Copyright: (c) 2012 Sakhale BK, et al. This is an open-access article distributed under the terms of the Creative Commons Attribution License, which permits unrestricted use, distribution, and reproduction in any medium, provided the original author and source are credited. 
mangoes can be stored by proper treatment for utilization in the lean season.

Beverages based on fruits and milk products are currently receiving considerable attention as their market potential is growing. Besides being delicious, these beverages are highly nutritious. They may be particularly useful in places where there is inadequate nutrition, which could lead to nutritional deficiency diseases. Therefore, to make the best use of dairy whey and mango fruit, the present study was conducted to develop delicious and nutritious beverages from the combinations of fruit pulp and milk products.

\section{Materials and Methods}

\section{Preparation of milk whey}

The standardized milk was heated to $82^{\circ} \mathrm{C}$ and acidified by adding 2 $\%$ citric acid with continuous stirring, which resulted in the coagulation of milk protein (casein). The liquid (whey) was separated by filtration as per the standard method [8]. The filtered whey was centrifuged at $45^{\circ} \mathrm{C}$ to remove the fat (Figure 1). The whey obtained was stored at $4 \pm$ $1^{\circ} \mathrm{C}$ and heated to $60^{\circ} \mathrm{C}$ before preparation of the beverage.

\section{Preparation of mango pulp}

The fresh fully ripened mangoes of Cv. Kesar were procured from the local market. The mango pulp was extracted by standard method [9] and stored at $4 \pm 1^{\circ} \mathrm{C}$ until use.

\section{Preparation of whey based mango RTS}

The whey based mango beverages were prepared by blending of whey and mango pulp in different proportions like $C_{1}(70: 30), C_{2}(75: 25)$ and $C_{3}(80: 20)$ respectively (Figure 2). The recipe for preparation of $1000 \mathrm{ml}$ beverages with addition of pulp in varying proportions is presented in table 1 . The sugar $10 \%$ and $0.1 \%(\mathrm{w} / \mathrm{v})$ sodium alginate were dissolved in whey by heating to $60^{\circ} \mathrm{C}$ and then filtered through muslin cloth. The fruits pulp was added to whey and homogenized. Thus prepared beverages was filtered and filled in previously sterilized glass bottles $(200 \mathrm{ml})$ leaving $2.5 \mathrm{~cm}$ head space and sealed airtight by crown corking. Then in bottle sterilization was done at $105^{\circ} \mathrm{C}$ for $10 \mathrm{~min}$ and cooled to room temperature and stored at $7 \pm 1^{\circ} \mathrm{C}$ for storage studies. Samples were drawn at a regular interval of 7 days and evaluated for various quality attributes.

\section{Proximate analysis}

The proximate analysis of whey, mango pulp and beverages were

The milk of $4.5 \%$ fat and $8.5 \%$ SNF was heated to $82^{\circ} \mathrm{C}$

$$
\downarrow
$$

Coagulated milk protein with citric acid $(2 \%)$

$$
\downarrow
$$

Heated to $82^{\circ} \mathrm{C}$ to precipitate protein

$\downarrow$

Filtered through muslin cloth

$$
\downarrow
$$

Centrifuged at $5000 \mathrm{rpm}$ for $10 \mathrm{~min}$

$$
\downarrow
$$$$
\text { Whey }
$$

Figure 1: Process flow chart for the preparation of paneer whey.

\author{
Whey \\ $\downarrow$ \\ Dissolved the sugar and stabilizer \\ Filtered \\ $\downarrow$ \\ Mixed filtrate and mango pulp and then blended uniformly \\ $\downarrow$ \\ Bottled in pre-sterilized glass bottles with $2.5 \mathrm{~cm}$ headspace \\ $\downarrow$ \\ In bottle sterilized \\ $\downarrow$ \\ Cooled \\ $\downarrow$ \\ Labeled \\ $\downarrow$ \\ Stored at $5-7^{\circ} \mathrm{C}$ temperature
}

Figure 2: Process flow chart for the preparation of whey based mango beverage.

\begin{tabular}{|l|c|c|c|}
\hline Ingredients & C1 & C2 & C3 \\
\hline Mango pulp (ml) & 300 & 250 & 200 \\
\hline Sugar $(\mathrm{g})$ & 100 & 100 & 100 \\
\hline Stabilizer \% (w/v) & 01 & 01 & 01 \\
\hline Whey $(\mathrm{ml})$ & 599 & 649 & 699 \\
\hline
\end{tabular}

Table 1: Recipe for preparation of whey based mango beverages $(1000 \mathrm{ml})$.

done for different parameters. The total soluble solids (TSS), protein, ash, ascorbic acid and total and reducing sugars were estimated by the standard methods [10]. The total acidity was calculated in terms of lactic acid for whey and citric acid for mango pulp by titrating against $0.1 \mathrm{~N} \mathrm{NaOH}$ [11]. Fat content was determined by Gerber's centrifuge method as described in the BIS [12]. Solids not fat of milk and whey were estimated by measuring the density of the sample with the help of lactometer and the readings were converted into \% SNF as per BIS [13].

\section{Organoleptic evaluation}

The fresh and stored beverage samples prepared with varying levels of mango pulp and whey were served chilled for organoleptic evaluation and it was carried out by semi-trained panel of ten judges on a 9.0 point Hedonic scale [14].

\section{Microbial Analysis}

Microbial analysis were carried out by taking $10 \mathrm{~mL}$ representative samples and aseptically mixed with $90 \mathrm{~mL}$ distilled water and homogenized by shaking. Subsequent decimal dilutions were prepared with the same diluents and in all cases duplicate-counting plates were prepared of appropriate dilutions [15]. Total viable count was carried out using the pour plate method [16], whereas yeasts and mould were enumerated by surface plating on malt extract agar (Oxoid) with $0.01 \%$ chloramphenicol as bacterial inhibitor and incubated aerobically at $25^{\circ} \mathrm{C}$ for $2-3$ days [15].

\section{Statistical analysis}

The data generated in the experiments were recorded and subjected to statistical analysis using standard procedure [17]. The standard errors (SE) and critical differences (CD) at 5\% level of significance 
were worked out for comparison of treatments and presented in the respective tables.

\section{Results and Discussion}

\section{Proximate analysis of whey and mango pulp}

The data pertaining to the various chemical characteristics of whey and mango pulp are presented in table 2 . It clearly indicates that whey and mango pulp were as expected rich in SNF and ascorbic acid respectively. Mango pulp was found better in TSS, total and reducing sugars contents whereas whey was better in protein, SNF, fat and total solids. The results obtained with respect to chemical characteristic are in agreement with the earlier studies [7,18-20].

\section{Effect of storage on physico-chemical parameters of whey base mango RTS}

Effect of addition of mango pulp on physic-chemical parameters of whey based mango RTS and changes during storage was studied and obtained results is presented in table 3. Physico-chemical properties of beverages such as total sugars, reducing sugars, $\mathrm{pH}$, ascorbic acid and overall acceptability were affected significantly by the level of mango pulp whereas it did not affect TSS and acidity [21].

A reducing trend was observed in total sugars and ascorbic acid whereas an increasing trend was observed in reducing sugars and acidity content during storage. No significant change was observed in TSS content of the beverages during 30 days of storage. Decreasing trend in total sugar and increasing trend in reducing sugar and titrable acidity was observed during 30 days storage. Increase in reducing sugars may be due to the conversion of sugar into reducing sugar in presence of citric acid. Also increase in per cent acidity might be due to the slight

\begin{tabular}{|l|c|c|}
\hline \multicolumn{1}{|c|}{ Parameter } & Whey & Mango pulp \\
\hline T.S.S ( ${ }^{\circ}$ Brix) & ND & 15 \\
\hline Total Solids (\%) & 6.12 & ND \\
\hline Acidity (\%) & 0.18 & 0.22 \\
\hline Total sugar (\%) & 3.22 & 9.8 \\
\hline Reducing sugar (\%) & ND & 5.08 \\
\hline Ascorbic acid (mg/100g) & ND & 24.0 \\
\hline Fat $(\%)$ & 0.19 & ND \\
\hline SNF (\%) & 5.73 & ND \\
\hline Protein (\%) & 0.45 & \\
\hline
\end{tabular}

ND - Not detected

Table 2: Proximate analysis of whey and mango pulp*.

\begin{tabular}{|c|c|c|c|c|c|c|}
\hline $\begin{array}{c}\text { Storage } \\
\text { period (days) }\end{array}$ & Beverages & $\begin{array}{c}\text { TSS } \\
\left({ }^{\circ} \text { Brix }\right)\end{array}$ & $\begin{array}{c}\text { Acidity } \\
(\mathbf{g} \%)\end{array}$ & $\begin{array}{c}\text { Ascorbic } \\
\text { acid } \\
(\mathrm{mg} / 100 \mathrm{~g})\end{array}$ & $\begin{array}{c}\text { Total } \\
\text { sugar } \\
(\mathbf{g} \%)\end{array}$ & $\begin{array}{c}\text { Reducing } \\
\text { sugar } \\
(\mathrm{g} \%)\end{array}$ \\
\hline \multirow{3}{*}{$\mathbf{0}$} & $\mathrm{C} 1$ & 15.7 & 0.36 & 9.80 & 11.09 & 3.40 \\
\cline { 2 - 7 } & $\mathrm{C} 2$ & 16.0 & 0.33 & 9.30 & 12.14 & 3.40 \\
\cline { 2 - 7 } & $\mathrm{C} 3$ & 16.0 & 0.32 & 7.60 & 11.50 & 2.92 \\
\hline \multirow{3}{*}{$\mathbf{1 5}$} & $\mathrm{C} 1$ & 15.7 & 0.37 & 9.74 & 11.00 & 3.45 \\
\cline { 2 - 7 } & $\mathrm{C} 2$ & 16.0 & 0.33 & 9.26 & 11.90 & 3.43 \\
\cline { 2 - 7 } & $\mathrm{C} 3$ & 16.0 & 0.33 & 7.53 & 11.20 & 2.97 \\
\hline \multirow{3}{*}{30} & $\mathrm{C} 1$ & 15.7 & 0.38 & 9.70 & 10.91 & 3.49 \\
\cline { 2 - 7 } & $\mathrm{C} 2$ & 16.0 & 0.34 & 9.21 & 11.71 & 3.50 \\
\cline { 2 - 7 } & $\mathrm{C} 3$ & 16.0 & 0.35 & 7.50 & 11.05 & 3.02 \\
\hline
\end{tabular}

*Each value is the average of three determinations. C1, C2 and C3 are the combinations with varying levels of whey and pulp. C1-70:30 (Whey: Pulp), C275:25 (Whey: Pulp), and C3-80:20 (Whey: Pulp)

Table 3: Effect of storage on physico-chemical characteristics of whey based mango RTS*
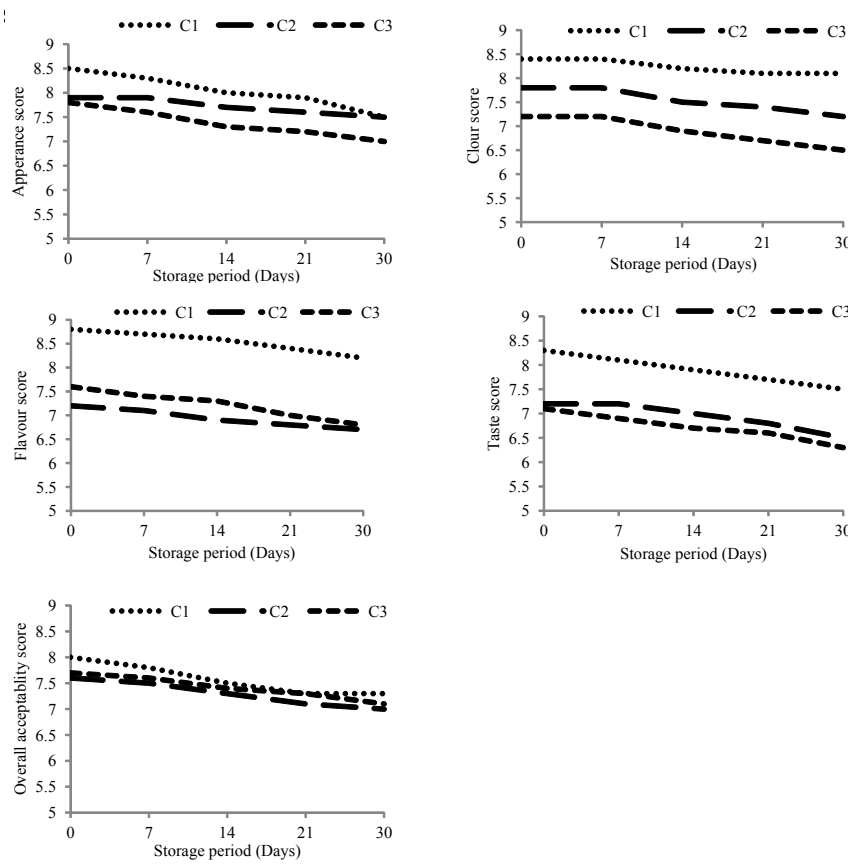

Figure 3: Effect of storage on organoleptic characteristic of whey based mango RTS.

growth of micro-organism in the beverage. The results obtained are in conformity with those of earlier results [19] with respect to whey-based papaya pulp blended RTS beverage stored at refrigeration temperature for the period of three months. Also results pertaining to ascorbic acid showed decreasing trend. This might be due to loss of ascorbic acid during storage due to auto-oxidation and light. Noted decline in the ascorbic acid content of muskmelon RTS beverage during six months storage [22].

\section{Sensory evaluation}

The beverages prepared by blending of whey and pulp in different combination were analyzed for various sensorial attributes for their acceptance by using 9 point hedonic scale. The sensory scores obtained with respect to color, flavor, taste and overall acceptability are presented in figure 3 . It is observed that beverage sample (C3) prepared by addition of $30 \%$ pulp was liked most by sensory panel members as compared to the other combinations. The color, flavor and taste of $\mathrm{C} 1$ beverage maintained the highest organoleptic score other than the $\mathrm{C} 2$ and C3 beverages respectively. The result revealed that decrease in level mango pulp lower down the sensory score of beverage. Shekilango et al. [23] also found that a blend of three parts (w/w) acid whey to two parts $(\mathrm{w} / \mathrm{w})$ banana was the most acceptable formula in terms of flavor. The storage study of whey based mango beverage revealed that all the characteristics i.e. appearance, colour, flavor, taste and overall acceptability of sensory evaluation was in decreasing trend. This might be due to changes occurred during storage of beverage.

\section{Microbial analysis}

The beverage samples were analysis periodically for total plate count and yeast and mold count. The data obtained with respect to microbial load are summarized in table 4 . Total plate counts of fresh beverage samples i.e. C1, C2 and C3 was $2.00 \times 10^{4} \mathrm{CFU} / \mathrm{mL}, 1.93 \times 10^{4} \mathrm{CFU} / \mathrm{mL}$ and $2.05 \times 10^{4} \mathrm{CFU} / \mathrm{mL}$ respectively. As the storage period proceed the 
Citation: Sakhale BK, Pawar VN, Ranveer RC (2012) Studies on the Development and Storage of Whey based RTS Beverage from Mango cV. Kesar. J Food Process Technol 3:148. doi:10.4172/2157-7110.1000148

Page 4 of 4

\begin{tabular}{|c|c|c|c|c|}
\hline \multirow{2}{*}{ Parameters } & \multirow{2}{*}{ Storage period } & \multicolumn{3}{|c|}{ Samples } \\
\hline & & C1 & $\mathrm{C} 2$ & C3 \\
\hline \multirow{5}{*}{$\begin{array}{l}\text { Total plate count } \\
\quad(\mathrm{CFU} / \mathrm{mL})\end{array}$} & 0 & $2.00 \times 10^{4}$ & $1.93 \times 10^{4}$ & $2.05 \times 10^{4}$ \\
\hline & 7 & $2.16 \times 10^{4}$ & $2.20 \times 10^{4}$ & $2.29 \times 10^{4}$ \\
\hline & 14 & $2.31 \times 10^{4}$ & $2.38 \times 10^{4}$ & $2.37 \times 10^{4}$ \\
\hline & 21 & $2.48 \times 10^{4}$ & $2.55 \times 10^{4}$ & $2.43 \times 10^{4}$ \\
\hline & 30 & $2.66 \times 10^{4}$ & $2.73 \times 10^{4}$ & $7.62 \times 10^{4}$ \\
\hline \multirow{5}{*}{$\begin{array}{l}\text { Yeast / mold count (CFU/ } \\
\mathrm{mL})\end{array}$} & 0 & ND & ND & ND \\
\hline & 7 & 3 & 5 & 5 \\
\hline & 14 & 6 & 7 & 9 \\
\hline & 21 & 16 & 14 & 15 \\
\hline & 30 & 21 & 19 & 24 \\
\hline
\end{tabular}

$\mathrm{ND}=$ not detected

Table 4: Microbial analysis of whey based mango RTS.

total plate count increases and after the completion of one month $(30$ days) storage it reaches to $2.66 \times 10^{4} \mathrm{CFU} / \mathrm{mL}, 2.73 \times 10^{4} \mathrm{CFU} / \mathrm{mL}$ and $2.62 \times 10^{4} \mathrm{CFU} / \mathrm{mL}$ in the beverage samples $\mathrm{C} 1, \mathrm{C} 2$ and $\mathrm{C} 3$ respectively. Yeast and mould count was not detected in all three samples (C1, C2 and C3) at zero day storage whereas it increases to 21, 19 and $24 \mathrm{CFU} / \mathrm{g}$ respectively after 30 days of storage. Similar results of total plate count were reported for whey-based mango beverage [24]. In spite of the potential benefits offered by fruit juices, concerns over their safety and quality have been raised; as freshly prepared juices have no process or steps to minimize the microorganisms if they are contaminated [25].

\section{Conclusion}

It can be concluded that whey can be found successful for the development of whey based mango beverages with optimum sensory characteristics. The nutritious beverages with better storage life could be developed by addition of whey up to certain extent. Mango based whey beverage have excellent color, flavor and stability was estimated to be high which means that mango pulp covered unpleasant taste of whey very successfully. An increase of both fruit and sucrose concentration might improve the characteristics of the blends. The sweetness of the product seems to be highly appreciated characteristic that must be related to the consumer habits.

\section{References}

1. Naik YK, Khare A, Choudhary PL, Goel BK, Shrivastava A (2009) Studies on physico-chemical and sensory characteristics of whey based watermelon beverage. Asian Journal of Research in Chemistry 2: 57-59.

2. Cruz AG, Ana ASS, Macchione MM, Teixeira AM, Schmidt FL (2009) Milk drink using whey butter cheese (Queijo manteiga) and Acerola juice as a potential source of vitamin C. Food and Bioprocess Technology 2: 368-373.

3. Pal RK (1998) Ripening and rheological properties of mango as influenced by ethereal and carbide. J Food Sci Technol 35: 358-360.

4. Gagrani RL, Rathi SD, Ingle UM (1986) Preparation of fruit flavored beverage from whey. J Food Sci Technol 24: 93-94.

5. Singh S, Ladkhani BG, Kumar A, Mathur BN (1994) Development of whey based beverage. Indian journal of dairy science 47: 586-590.

6. Singh W, Kapoor CM, Srivastava DN (1999) Standardization of Technology for the manufacture of guava-whey beverage. Indian journal of dairy science 52: $268-271$

7. Sikder B, Sarkar K, Ray PR, Ghatak PK (2001) Studies on shelf life of whey Based Mango Beverage. Beverage and Food World 28: 53-54.

8. De S (1991) Outlines of Dairy Technology. Oxford University Press, New Delhi.

9. Lal G, Siddappa GS, Tandon GL (1967) Preservation of fruits and vegetables. Indian council of agriculture research (ICAR), New Delhi. 294-297.

10. Ranganna S (1986) Handbook of Analysis and Quality Control for Fruits and Vegetable Products. Tata MaGraw hill Publishing Company Limited, New Delhi.

11. AOAC (1995) Official Methods of Analysis (16 $16^{\text {th }}$ Edn.), Association of Official Analytical Chemists, Washington, DC.
12. BIS (1977) IS: 1224: Part - II, Determination of fat by Gerber's method-Milk products. Bureau of Indian Standards, New Delhi.

13. BIS (1982) IS: 10083: Method of test for determination of SNF (Solid-not-fat) in milk by the use of lactometer. Bureau of Indian Standards, New Delhi.

14. Amerine MA, Pangborn RM, Roessler EB (1965) Principles of sensory evaluation of food. Academic press, New York

15. Harrigan WF, Mac-Cance ME (1976) Laboratory methods in food and dairy microbiology. Academic Press, London.

16. Harrigan WF (1998) Laboratory methods in food microbiology (3rd Edn) Academic Press, London.

17. Das MN, Giri NC (1988) Design and Analysis of Experiments ( $2^{\text {nd }}$ Edn). Wiley Eastern Ltd, New Delhi.

18. Ingale MP, Ranveer RC, Nagargoje KD (2009) Development of whey based custard apple (Annona Squamosa L.) beverage. Beverage Food world 36: 4344.

19. Saravana Kumar R, Manimegalai G (2005) Studies on storage stability of wheybased papaya juice blended RTS beverage. J Food Sci Technol 42: 185-188.

20. Shukla FC, Sharma A, Singh B (2004) Studies on the preparation of fruit beverages using whey and buttermilk. J Food Sci Technol 41: 102-105.

21. Patel S, Prashant S, Choudhary PL, Bakane PH (2006) Development and evaluation of whey based mango herbal (ginger) beverages. Beverage Food World 33: 15-19.

22. Teotia MS, Kaur S, Berry SK (1997) Utilization of muskmelon ready to serve beverage from enzyme clarified juice. Indian Food Packer 51: 11-17.

23. Shekilango SA, Jelen P, Bagdan GC (1997) Production of whey-banana beverages from acid whey and over ripe bananas. Milchwissenschaft 52: 209212

24. Ismail AE, Abdelgader MO, Azhari Ali A (2011) Microbial and Chemica Evaluation of Whey-Based Mango Beverage. Advance Journal of Food Science and Technology 3: 250-253.

25. Mahale DP, Khade RG, Vaidya VK (2008) Microbiological Analysis of Stree Vended Fruit Juices from Mumbai City, India. Internet Journal of Food Safety 10: $31-34$ 